\author{
JURNAL RESPIRASI \\ JR \\ Vol. 4 No. 1 Januari 2018
}

\title{
Imunopatogenesis Penyakit Paru Obstruktif Kronik
}

\author{
Resti Yudhawati, Yuyus Dwi Prasetiyo \\ Departemen Pulmonologi dan Ilmu Kedokteran Respirasi, Fakultas Kedokteran Universitas Airlangga/RSUD Dr. Soetomo, Suarabaya
}

\begin{abstract}
Chronic Obstructive Pulmonary Disease (COPD) is an inflammatory airway disease and complicated lung tissue. The airways of patients with COPD contain many inflammatory cells including neutrophils, macrophages, CD8 T lymphocytes, CD4 T lymphocytes and dendritic cells, each of which has its own role and interacts with COPD immunopathogenesis. The inflammatory response in people with COPD involves innate immunity (neutrophils, macrophages, eosinophils, mast cells, natural killer cells, and dendritic cells) and adaptive immunity ( $T$ and B lymphocytes), but there is also activation of structual cells such as alveolar epithelial cells endothelial cells and fibroblasts. Inflammation of the respiratory tract in COPD will persist even after quitting smoking, this can be caused by damage to the extracellular matrix will release proinflammatory cytokines which are neutrophil and monocyte chemotaxis, impaired alveolar macrophages which result in impaired cleaning of apoptotic cells and pathogenic microbes and oxidative stress will cause DNA double chain damage.
\end{abstract}

Keywords: COPD, Immunopathogenesis, Inflammatory response

Correspondence: Resti Yudhawati, Departemen Pulmonologi dan Ilmu Kedokteran Respirasi, Fakultas Kedokteran Universitas Airlangga/ RSUD Dr. Soetomo. Jl. Mayjen. Prof. Dr. Moestopo 6-8 Surabaya 60286. E-mail: restiyudhawati@gmail.com

\section{PENDAHULUAN}

Penyakit Paru Obstruktif Kronik (PPOK) adalah penyakit paru yang dapat dicegah dan diobati, ditandai dengan adanya keterbatasan aliran udara yang persisten dan umumnya bersifat progresif, berhubungan dengan respons inflamasi kronik yang berlebihan pada saluran napas dan parenkim paru akibat gas atau partikel berbahaya. Karakteristik hambatan aliran udara pada PPOK disebabkan oleh gabungan antara obstruksi saluran napas kecil dan kerusakan parenkim yang bervariasi pada setiap individu, akibat inflamasi kronik yang menyebabkan gangguan hubungan alveoli dan saluran napas kecil dan penurunan elastisitas rekoil paru. ${ }^{1,2}$

PPOK seringkali diderita pasien usia pertengahan dan berhubungan dengan berbagai faktor risiko seperti merokok, polusi udara, usia, dan lain-lain. Data Badan Kesehatan Dunia (WHO), menunjukkan tahun 1990 PPOK menempati urutan ke-6 sebagai penyebab utama kematian di dunia, pada tahun 2002 PPOK menempati urutan ke-5 dan diperkirakan pada tahun 2030 akan menjadi penyebab kematian ke-3 di seluruh dunia setelah penyakit kardiovaskuler dan kanker., ${ }^{1,2}$
Dalam sebuah telaah sistematis dan meta analisis pada 28 negara antara tahun 1990 dan 2004 serta ditambah penelitian dari Jepang disebutkan bahwa prevalensi PPOK lebih tinggi diderita pada perokok dan mantan perokok dibanding bukan perokok, dengan usia $>40$ tahun lebih banyak dibanding $<40$ tahun, dengan prevalensi pria lebih tinggi dibanding wanita. The Latin American Project for the Investigation of Obstructive Lung Disease (PLATINO) memperkirakan prevalensi PPOK meningkat bertahap sesuai umur, tertinggi usia $>60$ tahun. ${ }^{1,2,3}$

Inflamasi pada saluran napas pasien PPOK merupakan modifikasi dari respons inflamasi saluran napas terhadap iritasi kronik seperti asap rokok. Mekanisme secara pasti dari inflamasi ini masih belum dipahami secara baik serta dipengaruhi oleh genetik. Timbulnya stres oksidatif dan meningkatnya protease pada paru akan memodifikasi respons inflamasi

\section{Faktor Risiko}

Faktor risiko terjadinya PPOK melibatkan faktor pejamu dan paparan lingkungan, dan penyakit ini terjadi biasanya karena interaksi antara kedua faktor tersebut. Faktor 
pejamu adalah adanya defisiensi dari alpha 1 antitrypsin (a1-AT) sebagai inhibitor dari protease serin, dan sifat resesif ini jarang ditemukan. Asap rokok merupakan faktor lingkungan yang paling sering menyebabkan terjadinya PPOK, akan tetapi ada beberapa faktor risiko yang lain seperti polusi udara, paparan zat ditempat kerja, pria, usia tua, infeksi berulang, status sosial ekonomi, asma dan bronkitis kronik. Paparan terhadap asap rokok dan sisa pembakaran kendaraan bermotor juga berperan penting terutama pada bukan perokok dan wanita. ${ }^{1,2}$

\section{Patogenesis PPOK}

Patogenesis terjadinya PPOK belum sepenuhnya diketahui walaupun beberapa teori telah dikemukakan. Ada beberapa mekanisme utama terjadinya PPOK, yaitu adanya proses inflamasi kronik pada saluran napas, stress oksidatif, gangguan keseimbangan antara proteolitik dan anti proteolitik. Inflamasi kronik dari saluran napas karena masuknya sel inflamasi ke paru sebagai respons terhadap asap rokok. Beberapa sel inflamasi seperti makrofag, netrofil, sel T CD8+ telah diketahui berperan dalam proses inflamasi pada saluran napas pasien PPOK. Stres oksidatif yang dapat menyebabkan gangguan fungsi sel atau bahkan kematian sel serta dapat menginduksi kerusakan matriks ekstraseluler paru. ${ }^{3}$

Stres oksidatif selanjutnya akan mempengaruhi keseimbangan antara proteolitik dan anti proteolitik melalui aktivasi protease dan mengnonaktifkan antiproteinase. Gangguan keseimbangan antara proteolitik dan anti proteolitik pada paru, mengakibatkan kerusakan parenkim paru sehingga terjadi emfisema. Peningkatan aktivitas proteolitik ini merupakan konsekuensi dari respons inflamasi, yaitu pelepasan enzim proteolitik oleh sel inflamasi seperti makrofag dan netrofil atau juga karena faktor genetik yaitu defisiensi a1-antitripsin. ${ }^{3}$

\section{Sel Inflamasi pada PPOK}

Respons inflamasi pada pasien PPOK selain melibatkan kekebalan bawaan (netrofil, makrofag, eosinofil, sel mast, natural killer cells, dan sel dendritik) dan kekebalan adaptif (limfosit $\mathrm{T}$ dan $\mathrm{B}$ ), tetapi juga ada aktivasi terhadap sel-sel struktural seperti sel epitel alveolar, sel endotel dan fibroblast.

\section{Sel epitel}

Aktivasi sel epitel oleh asap rokok maupun bahan polutan yang lain akan melepaskan mediator inflamasi seperti TNFa, IL1ß, IL-6, GM-CSF dan CXCL8 (IL-8). Sel epitel pada saluran napas kecil sebagai sumber dari transforming growth factor (TGF) beta yang akan menginduksi terjadinya fibrosis lokal. Vascular endothelial growth factor (VEGF) dibutuhkan untuk mempertahankan integritas dari sel alveolar, dan memblokade reseptor VEGFR2.4,5

Sel epitel pada saluran napas juga penting untuk pertahanan saluran napas, melalui produksi mukus oleh sel goblet dan mensekresi anti oksidan, antiprotease, dan defensins/cathelicidins. Asap rokok dan agen noxius (berbahaya) yang lain akan mengakibatkan gangguan dari respons sel epitel dan lebih rentan terhadap infeksi. Epitel saluran napas pada pasien bronkitis kronik dan PPOK sering bermetaplasia menjadi epitel skuamus oleh karena proses proliferasi yang meningkat pada lapisan basal sel epitel. Epithelial growth faktor receptors (EGFRs) menunjukkan peningkatan ekspresi pada sel epitel pasien PPOK dan berkontribusi terhadap proliferasi sel basal, yang menyebabkan metaplasia skuamus dan risiko terjadinya karsinoma bronkial (Gambar 1). ${ }^{4}$

Hiperplasia mukus banyak dijumpai pada pasien PPOK sebagai respons terhadap iritasi kronik saluran napas oleh asap rokok dan polusi yang lain. EGFRs memegang peranan penting pada hiperplasia dan sekresi mukus dan diaktivasi oleh inflamasi netrofilik melalui sekresi neutrophil elastase (NE), yang melepaskan TGF-a. Stres oksidatif juga mampu mengaktivasi EGFRs dan menginduksi hipersekresi mukus. ${ }^{4}$

\section{Makrofag}

Peningkatan jumlah makrofag pada perokok dan PPOK disebabkan oleh penarikan monosit dari sirkulasi sebagai respons terhadap monocyte selective chemokine di paru. Monocyte selective chemokine didapatkan meningkat pada sputum dan cairan BAL pasien PPOK. ${ }^{6}$

Kemokin CXC juga bertindak seperti chemoattractants monosit melalui CXCR2. Didapatkan peningkatan konsentrasi dari kemokin CXC GRO-alfa yang secara selektif mengaktifkan CXCR2 pada sputum dan cairan BAL pasien PPOK. Monosit pada PPOK menjadi lebih responsif terhadap GRO-alfa dibanding sel pada perokok normal dan bukan perokok. ${ }^{6,7}$

Selain itu peningkatan jumlah makrofag juga disebabkan oleh peningkatan proliferasi dan bertambahnya usia makrofag di paru. Makrofag mempunyai tingkat proliferasi yang rendah di paru, tetapi dengan pengukuran proliferative cell nuclear antigen (PCNA) tampak peningkatan proliferasi sel makrofag pada perokok dibandingkan pada normal dan makrofag pasien asma, begitu juga pada pasien dengan inflamasi kronik di paru dengan penyebab yang lain. 6,7

Makrofag alveolar memiliki kemampuan melepaskan berbagai kemokin yang akan menyebabkan penarikan beberapa tipe sel dari sirkulasi, termasuk monosit, netrofil, dan limfosit T. IL-8 akan dilepaskan oleh makrofag sebagai respons terhadap beberapa stimuli, termasuk asap rokok, endotoksin dan IL-1ß. Hipoksia juga merangsang makrofag untuk melepaskan IL-8, dan mekanisme ini berhubungan dengan PPOK berat dan eksaserbasi. Makrofag alveolar pada PPOK melepaskan IL-8 lebih banyak pada kondisi basal dan setelan stimuli oleh IL- 13 dan asap rokok dibanding makrofag pada perokok normal dan bukan perokok. 6,7

Makrofag juga mampu melepaskan CXCL10, CXCL11 dan CXCL9, yang merupakan agen kemotaksis terhadap sel Tc CD8+ melalui interaksi dengan reseptor CXCR3. Makrofag memegang peranan penting pada proses penarikan sel limfosit $\mathrm{T}$ terutama sel CD8+ ke dalam paru. 


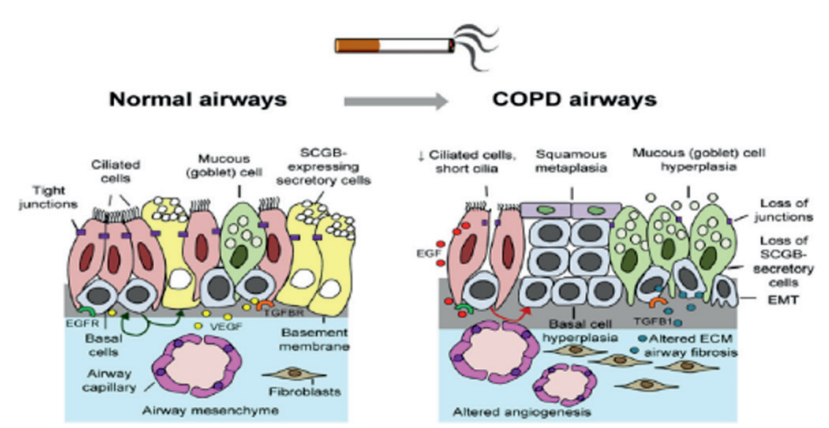

Gambar 1. Perubahan lapisan epitel saluran napas akibat rokok. ${ }^{4}$

Pelepasan interferon- $\gamma$ juga akan merangsang lebih jauh pelepasan kemokin dan menghasilkan siklus inflamasi kronik. 6,7,8

Makrofag alveolar juga melepaskan sitokin inflamasi seperti TNF-a sebagai respons terhadap asap rokok (Gambar 2) dan hal ini berkontribusi pada peningkatan konsentrasi TNF-a pada sputum pasien PPOK. GMCSF juga dilepaskan dari makrofag, tapi tidak seperti kemokin lain dan TNF- a, pelepasan GM-CSF ini tidak meningkat pada PPOK. Makrofag alveolar pasien PPOK melepaskan TGF- $\beta$ lebih banyak dibanding sel pada orang normal maupun asma. Makrofag pasien PPOK menunjukan peningkatan ekspresi terhadap TGF- $\beta$ dan hal ini berkontribusi terjadinya fibrosis pada saluran napas kecil. Makrofag alveolar juga memproduksi TGF- $\beta$ dan merupakan activator endogen dari reseptor epidermal growth factor (EGF) yang memegang peranan penting dalam regulasi sekresi mukus sebagai respons terhadap berbagai rangsangan termasuk asap rokok. 6,7,8

Asap rokok akan mengaktivasi dan menghimpun berbagai komponen NADPH oxidase pada sel membrane makrofag yang menghasilkan anions yang akan dirubah menjadi hidrogen peroksida oleh superoxide dismutase. Produksi ROS (Reactive Oxygen Species) penting bagi makrofag untuk membunuh bakteri, tapi juga penting untuk mengaktifkan MAP kinase signal transduction pathways, faktor transkripsi NF-KB dan AP1 yang akan mengaktifkan gen multipel inflamasi. Makrofag alveolar juga menghasilkan beberapa enzim elastolitik seperti MMP-2, MMP-9, MMP-12, Cathepsins K, L dan S dan NE yang diambil dari netrofil. Enzim elastolitik yang dominan dihasilkan oleh makrofag adalah MMP-9. 7,8

Pada pasien PPOK kemampuan fagositosis makrofag alveolar dan monosit menurun terhadap bakteri. Hal ini merupakan faktor yang menyebabkan terjadinya kolonisasi bakteri pada saluran napas bawah seperti Haemophilus influenzae atau Streptococcus pneumoniae. Makrofag pada pasien PPOK juga mengalami gangguan dalam membersihkan sel apoptosis, hal ini berkontribusi dalam kegagalan menyelesaikan proses inflamasi pada pasien PPOK. 6,7,8

\section{Netrofil}

Pada cairan bronchoalveolar lavage (BAL) dan sputum pasien PPOK didapatkan peningkatan jumlah netrofil aktif dan berhubungan dengan tingkat keparahan penyakit PPOK. Merokok memberikan efek langsung terhadap produksi granulosit dan pelepasan dari sumsum tulang, dan dimediasi oleh GM-CSF dan pelepasan granulocyte colony-stimulating factor (G-CSF) dari makrofag paru. Migrasi netrofil ke saluran napas dan parenkim paru juga melibatkan ekspresi molekul adesi ke sel endotel melalui E-selectin. Studi patologi menunjukkan peningkatan ekspresi E-selectin terhadap sel endotel vaskular. Migrasi netrofil juga dipengaruhi oleh beberapa faktor kemotaksis netrofil seperti LTB4, CXCL1, CXCL5, dan CXCL8, dimana kadarnya juga meningkat pada pasien PPOK. Mediator-mediator ini berasal dari makrofag alveolar, Sel $\mathrm{T}$, dan sel epitel, akan tetapi netrofil merupakan sumber utama dari CXCL8. ${ }^{8,9}$

Netrofil melepaskan protease serine, termasuk NE, cathepsin G, dan proteinase-3, dan juga MMP-8 dan MMP-9 yang menyebabkan kerusakan alveoli. Netrofilia saluran napas berhubungan dengan hipersekresi mukus oleh karena NE, cathepsin G, dan proteinase-3 merupakan stimulator yang poten mensekresi mukus dari kelenjar submukosa dan sel goblet. Netrofil akan mensekresikan NE dimana aktivitas proteolitik NE tidak hanya menghancurkan patogen namun juga mendegradasi jaringan matriks tubuh dengan cara menciptakan ketidakseimbangan proteaseantiprotease pada PPOK. ${ }^{8,9,10}$

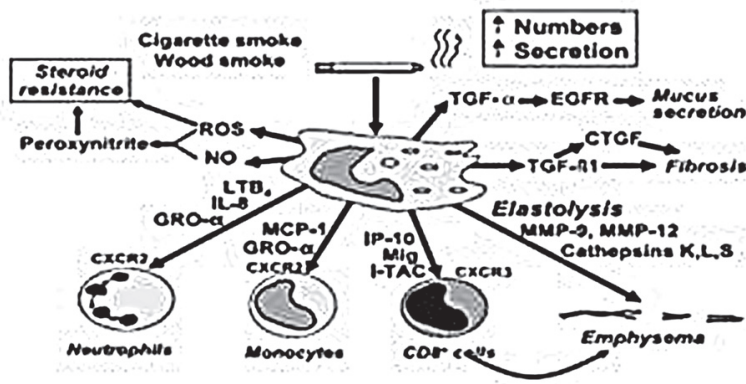

Gambar 2. Peran utama makrofag alveolar pada PPOK. ${ }^{8}$

\section{Sel dendritik}

Sel dendritik (DCs) memegang peranan penting dalam inisiasi respons kekebalan bawaan dan adaptif dan dipercayai DCs menghubungkan keduanya. Pada saluran napas dan parenkim paru didapatkan DCs yang terletak dekat permukaan.

\section{Respons Awal Terhadap Asap Rokok}

Induksi kekebalan bawaan terjadi sebagai respons dari berbagai mikroba melalui pengenalan terhadap molekul yang dimiliki mikroba disebut pattern associated molecular 
patterns (PAMPs). Pengenalan ini akan ditangkap oleh beberapa kelompok pattern recognition receptors (PRRs) yang diekspresikan oleh makrofag alveolar, sel dendritik, dan sel epitel yang pertama kali kontak dengan pathogen. Selain itu PRRs juga teraktivasi oleh molekul spesifik endogen intraselular, tetapi dilepaskan apabila sel mengalami kerusakan dan disebut damage associated molecular patterns (DAMPs). Pengenalan PAMPs dan DAMPs oleh PRRs sangat penting untuk terjadinya respons inflamasi terhadap infeksi dan kerusakan jaringan yang steril. ${ }^{15}$ Gambaran respons awal terhadap asap rokok dapat dilihat pada Gambar 3.

Berdasarkan hipotesis bahaya oleh Matzinger “danger signals" atau DAMPs dari sel yang rusak dapat mengaktifkan sistem imun melalui aktivasi PRRs. Paparan akut terhadap asap rokok dan partikel gas berbahaya lainnya dapat menyebabkan kerusakan sel-sel di paru, yang dapat menginduksi berbagai tipe kematian sel baik yang terprogam maupun tidak terprogram seperti apoptosis, nekrosis dan nekroptosis. Kematian sel ini akan melepaskan DAMPs seperti high mobility group box 1 (HMGB1), heat shock proteins dan protein S100, asam urat, dan ATP ke rongga ekstraseluler dan akan mengaktivasi beberapa PRRs dari sel yang terdekat. PRRs akan teraktivasi secara langsung baik oleh komponen yang dihasilkan rokok maupun tidak langsung akibat kerusakan sel epitel yang melepaskan DAMPs. Setelah berikatan dengan PRRs, sel epitel menjadi aktif dan melepaskan sitokin proinflamasi seperti TNF, IL-6, IL-8 dan interferon tipe I (IFN). ${ }^{14,15,16}$

Sitokin pro inflamasi dapat mengaktifkan dan menarik sel-sel inflamasi dari sistem kekebalan bawaan seperti netrofil, makrofag, dan sel dendritik, begitu juga dengan sel dari sistem kekebalan adaptif seperti sel limfosit $\mathrm{T}$ dan B. Netrofil dan makrofag yang teraktivasi dapat menyebabkan kerusakan paru melalui pelepasan radikal oksigen dan enzim proteolitik seperti NE dan MMPs, termasuk MMP-8, MMP-9 dan MMP-12. ${ }^{16}$

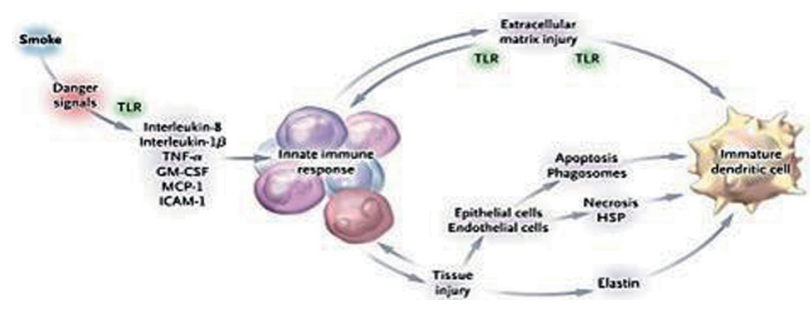

Gambar 3. Respons awal terhadap asap rokok. ${ }^{16}$

\section{Aktivasi Sel T dan Proliferasi}

Sel dendritik yang belum matang memberi kewaspadaan pada sistem kekebalan adaptif akan keberadaan patogen atau kerusakan jaringan. Sel ini menjadi matang ketika TLR berikatan dengan ligand. Sel dendritik matur akan mengekspresikan protein major histocompatibility complex class II (MHC) dan merangsang molekul CD80 dan CD 86, yang langsung membawa ke kelenjar limfe lokal, dimana mereka akan mengenalkan antigen kepada sel $\mathrm{T}$. Ekspresi dari IL-12 oleh sel dendritik akan mengaktifkan sinyal transduser dan activator of transcription (STAT4) yang menginduksi sel $\mathrm{T}$ berdiferensiasi menjadi sel $\mathrm{T}$ type 1 helper (Th1), yang akan memproduksi interferon $\gamma$. Pada perokok dengan PPOK tampak jelas peningkatan sel dendritik matang pada saluran napas perifer, yang sepertinya berhubungan dengan ekspresi yang tinggi dari chemoattractant sel dendritik CCL20 di paru. Tampak juga peningkatan sel T CD4+ yang mengekspresikan STAT4 di paru. ${ }^{14,16}$

Material dari paru perokok karena stres, kerusakan dan sel nekrosis serta dari sel apoptosis akan diambil oleh sel dendritik-molekul MHC dibawa ke limfosit T CD8+. Sel T naive tidak dapat masuk ke parenkim paru diluar pembuluh darah, tapi sekali teraktifasi oleh sel dendritik pembawa antigen mereka dapat masuk ke paru melalui reseptor kemokin yang spesifik. Pada paru perokok dengan PPOK, sel T CD8+ dan CD4+ akan mengekspresikan reseptor CXCR3, CCR5 dan CXCR6. ${ }^{16}$

\section{Respons Kekebalan Adaptif}

Baik pada saluran napas maupun parenkim paru, sel $\mathrm{T}$ sitotoksik CD8+ merupakan sel $\mathrm{T}$ predominan pada pasien PPOK. Sel T CD8+ pada PPOK akan meningkat sesuai dengan derajat hambatan aliran udara dan emfisema. Reseptor kemokin CXCR3 akan diekspresikan pada limfosit T tipe 1 dan ligan CXCL10 akan meningkat pada saluran napas perokok dengan PPOK, hal ini mengindikasikan bahwa hubungan antara CXCL10 dan CXCR3 berimplikasi terhadap penarikan sel T CD8+ pada PPOK. Sel T CD8+ yang teraktivasi akan melepaskan enzim proteolitik seperti perforin dan granzyme, yang dapat menyebabkan kematian sel dan kerusakan struktur sel melalu apoptosis maupun karena nekrosis. ${ }^{14,16}$

Sejumlah sel T CD4+ akan meningkat di dalam saluran napas dan parenkim paru pada perokok dengan PPOK. Setidaknya ada dua tipe dari efektor sel T CD4+ yang terakumulasi di paru pada pasien dengan PPOK stabil, yaitu sel Th1 dan sel Th17. Sel Th1 akan mensekresi lebih banyak IFNy, dan menyebabkan akumulasi sel inflamasi di paru. Sementara sel Th17 akan mengatur inflamasi jaringan melalui produksi IL-17A dan IL-17F. Sitokin Th17 akan menginduksi sel epitel untuk memproduksi peptide anti mikroba, kemokin, dan granulocyte growth faktor G-CSF dan GM-CSF dan akan menyebabkan penumpukan netrofil di lokasi kerusakan jaringan. ${ }^{14}$

Perokok dengan PPOK secara signifikan memiliki sel regulatory $\mathrm{T}$ (TREG) yang lebih rendah di paru serta kadar IL-10 juga rendah di paru. TREG merupakan bagian dari sel T CD4+ memiliki fungsi sebagai regulator kekebalan, yang akan menghambat proses autoimun dan menekan inflamasi. TREG akan menggunakan efek supresinya terhadap sel $\mathrm{T}$ yang lain atau antigen-presenting sel dendritik dengan memproduksi sitokin anti inflamasi seperti IL-10 dan TGF B. ${ }^{14,17}$ 


\section{Sel B}

Sel B meningkat pada saluran napas besar pasien PPOK, seperti ditunjukkan pada spesimen biopsi dari bronkus sentral. Sel B terorganisasi masuk kedalam folikel limfoid pada saluran napas kecil dan parenkim paru, khususnya pada pasien PPOK berat dan sangat berat. Seperti pada jaringan lain yang terinfeksi kronik, folikel limfoid pada PPOK dihasilkan dari neogenesis limfoid dan termasuk dalam inducible Bronchus Lymphoid Tissue (iBALT). ${ }^{14,18}$

Folikel limfoid secara anatomi dan fungsional teerorganisir dengan baik dan mengandung sel B memori dan sel B naive, sel T, sel dendritik, sel folikuler dendritik. B-cell activating factor of tumour necrosis factor family (BAFF) didapatkan meningkat didalam folikel pada PPOK jika dibandingkan dengan kontrol. Hal ini sama seperti pada pasien dengan emfisema, sehingga BAFF memegang peranan penting dalam pembentukan dan mempertahankan limfoid folikel pada PPOK. ${ }^{18}$

CCL19 dan CCL21 akan menarik limfosit $\mathrm{T}$ naive dan berekspresi terhadap CCR7 dan sel dendritik matur ke dalam area sel T, dimana CXCL13 akan menarik sel B dan berekspresi pada CXCR5. Sedangkan limfotoksin alfa dari kelenjar limfe akan menginduksi kemokin CCL19 dan CXCL13, dan IL-17 diperlukan untuk menginduksi kemokin ini pada iBALT. Sekali terbentuk iBALT ini akan bersifat tahan lama dan berperan dalam respons kekebalan lokal. ${ }^{19}$

Sel B secara alami merupakan suatu oligoklonal dan akan diinduksi oleh antigen spesifik, akan tetapi antigen yang terlibat belum diketahui, bisa antigen mikroba, cigarette smoke-derived antigen, pemecahan matriks ekstraseluler atau autoantigen. Oleh karena itu peran patogen dari respons sel folikular B masih kontroversial, akan menguntungkan jika melindungi dari kolonisasi bakteri dan infeksi saluran napas bawah, dan akan berbahaya jika melawan antigen jaringan paru yang merupakan komponen autoimun dan khususnya pada emfisema. ${ }^{16}$

\section{Stres Oksidatif}

Stres oksidatif merupakan mekanisme lainnya yang telibat dalam patogenesis PPOK dimana produksi yang berlebih dari spesies oksigen reaktif memperberat mekanisme pertahanan antioksidan. Oksidan diproduksi karena pengaruh asap rokok dan juga dilepaskan oleh leukosit inflamasi dan epitel alveolar serta sel endotel. Stres oksidatif dapat menyebabkan disfungsi sel atau apoptosis dan kerusakan matriks ekstra seluler paru. ${ }^{20}$

Stres oksidatif yang berkesinambungan terjadi karena adanya sumber dari endogen seperti mitokondria respirasi (Gambar 4). Sel epitel saluran napas jika terpajan stres karbonil akan menginduksi produksi mitochondriaderived ROS, dan otot polos saluran napas pasien PPOK menghasilkan sejumlah besar mitochondria-derived ROS. Selain itu sumber ROS intraseluler yang lain adalah NADPH oxidase (NOX) dan xanthine oxidase yang didapatkan meningkat pada BAL pada pasien PPOK. ${ }^{20}$
ROS berhubungan dengan oksidasi protein, lemak, karbohidrat dan DNA. Hasil utamanya adalah pembentukan reactive carbonyls dan reaksi dengan protein dikenal sebagai protein carbonylation. Penumpukan reactive carbonyls dan protein carbonylation disebut "carbonyl stress".

Oksidan berkontribusi pada proses inflamasi pada PPOK dengan mengaktivasi faktor transkripsi NF-kB yang menyebabkan transkripsi dari gen pro inflamasi. Selain itu oksidan juga bereaksi dengan asam lemak tak jenuh ganda dari sel membran dan membentuk peroksidase lipid seperti hidroperoksida, endoperoksida dan aldehid seperti etan, pentan, malondialdehid dan 4-hidroksi-2-nonenal yang sangat reaktif. Peroksidase lipid akan merusak sel membran dan menyebabkan kerusakan sel dan hasil peroksidase lipid bereaksi dengan DNA yang menyebabkan perubahan struktur DNA. ${ }^{20}$

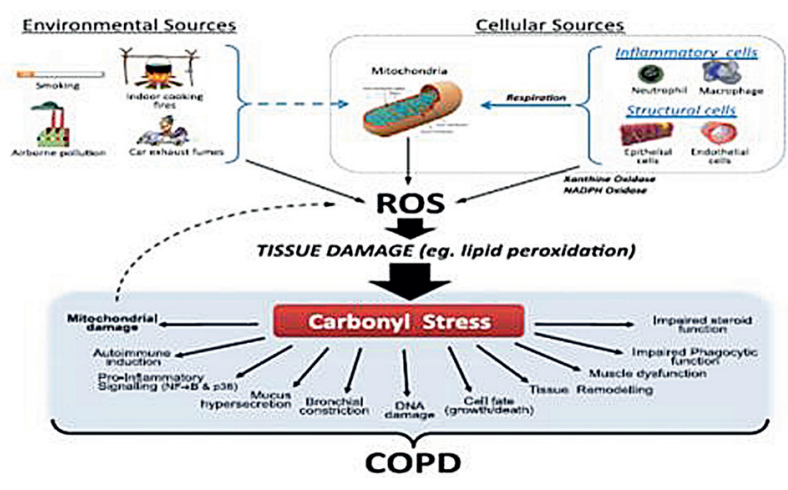

Gambar 4. Stres oksidatif pada PPOK. ${ }^{20}$

\section{Ketidakseimbangan Antara Protease dan Antiprotease}

Merokok dapat menginduksi peningkatan netrofil dan makrofag ke paru dan akan melepaskan enzim proteolitik. Pelepasan protease tidak sepenuhnya dihambat oleh anti protease, sehingga menyebabkan terjadinya proteolisis dari jaringan paru khususnya elastin dan terjadi emfisema.

Beberapa bukti telah menunjukkan bahwa salah satu penyebab utama PPOK berhubungan dengan defisiensi dari AAT (Alfa-1 Anti Trypsin), dimana AAT merupakan penghambat utama dari NE. Pada AAT perlindungan anti elastase pada interstitial paru dan rongga alveoli menurun sekitar 15-20\% dari kadar normal, dan tidak dapat memberikan perlindungan penuh terhadap NE. ${ }^{21}$

Kekurangan AAT diketahui sebagai faktor risiko terjadinya PPOK. AAT menghambat NE dan melindungi paru dari kerusakan yang di induksi oleh NE. Anti proteinase seperti a1 proteinase inhibitor (a-1-PI) dan anti leukoprotease akan di nonaktifkan oleh oksidan, menyebabkan gangguan keseimbangan antara proteinase dan anti proteinase yang menyebabkan kerusakan elastin dan jaringan ikat dan menyebabkan terjadinya emfisema. ${ }^{21}$

Merokok akan menginduksi pelepasan NE dan peningkatan level NE di plasma dan cairan BAL. Sekali NE berikatan dengan elastin, elastase akan terus aktif dan tidak dihambat oleh a1-antitrypsin. Studi patologi terhadap 
perokok muda didapatkan peningkatan makrofag pada bronkiol respirasi, dimana terjadi pembentukan emfisema sentrilobular tanpa defisiensi antitripsin, diduga makrofag memegang peranan penting. Beberapa enzim elastolitik dihasilkan oleh makrofag alveolar seperti cathepsin L dan S, MMP2, MMP9, dan MMP12 (gambar 5). ${ }^{21}$

\section{Inflamasi Kronik Saluran Napas pada PPOK}

Inflamasi saluran napas pada PPOK akan menetap meskipun telah berhenti merokok, hal ini dapat disebabkan oleh karena kerusakan matriks ekstraseluler akan melepaskan sitokin proinflamasi yang merupakan kemotaksis netrofil dan monosit. Kemokin CXC dan fragmen matriks ekstraseluler merupakan mediator yang menarik netrofil ke lokasi kerusakan.

Pada PPOK proses pembersihan sel apoptosis yang penting untuk pemulihan inflamasi dan untuk mempertahankan integritas paru mengalami gangguan karena menurunnya fungsi fagositosis makrofag alveolar, dan di sisi lain proses apoptosis pada PPOK mengalami peningkatan. Kegagalan dalam fagositosis sel apoptosis akan menyebabkan pelepasan DAMPs, NE dan komponen toksik lainnya ke dalam rongga ekstraseluler. Selain itu gangguan respon kekebalan bawaan merupakan faktor predisposisi terjadinya kolonisasi mikroba dan infeksi pada saluran napas bawah yang menyebabkan kerusakan epitel dan menyebabkan inflamasi yang menetap pada PPOK. ${ }^{14}$

Two hit hypothesis oleh Aoshiba et al. merupakan hipotesa yang menjelaskan mengapa inflamasi pada pasien PPOK menjadi kronik. Hipotesa ini terdiri dari inflamasi awal oleh karena sinyal bahaya dan inflamasi menetap oleh karena kerusakan DNA. Pada hipotesa ini disebutkan yang pertama adalah aktivasi kekebalan bawaan oleh sinyal bahaya merupakan pemicu awal terjadinya proses inflamasi pada perokok. Yang kedua adalah karena adanya faktor predisposisi genetik yang menfasilitasi terjadinya inflamasi, infiltrasi sel inflamasi ke dalam paru perokok yang memiliki faktor predisposisi genetik yang kuat menjadi PPOK lebih banyak dibanding perokok tanpa predisposisi PPOK. Karena kekurangan antioksidan dalam sistem pertahanan perokok yang "sesuai" sehingga makin banyak ROS dan RNS (Reactive Nitrogen Species) dilepaskan oleh sel inflamasi bersamaan dengan ROS yang ada pada rokok menyebabkan pecahnya rantai ganda pada sel saluran napas dan sel alveolar. Sebagai hasilnya terjadi apoptosis dan induksi senescence cells pada saluran napas dan sel alveolar, dan mengaktivasi respons kerusakan DNA dan senescence-associated secretory phenotype (SASP) yang menghasilkan sitokin pro inflamasi. Sitokin pro inflamasi ini akan merangsang infiltrasi sel inflamasi, membentuk umpan balik positif dimana senescence cell menjadi lebih intensif dan meninkatkan produksi sitokin inflamasi melalui SASP. Inflamasi kronik pada PPOK diduga karena siklus ganas antara inflamasi dengan kerusakan DNA yang terjadi sebagai hasil umpan balik positif. Akan tetapi sebaliknya pada perokok yang sehat tidak terjadi kerusakan DNA oleh karena rendahnya infiltrasi sel inflamasi yang akhirnya
ROS atau RNS yang dihasilkan juga lebih sedikit, sehingga adaptasi yang lebih efektif, mekanisme perbaikan DNA yang lebih efisien. ${ }^{22}$

\section{RINGKASAN}

PPOK merupakan penyakit inflamasi saluran napas dan jaringan paru yang rumit, dengan model penelitian terbanyak adalah menggunakan model pajanan asap rokok. Kelainan dini pada paru akibat rokok adalah hiperplasia sel basal, hiperplasia dan hipersekresi mukus oleh sel goblet, metaplasia sel skuamosa, epithelial-mesenchymal transition dan penurunan integritas barrier junctional. Saluran napas pasien PPOK mengandung banyak sel-sel radang termasuk netrofil, makrofag, limfosit T CD8, limfosit T CD4 dan sel dendritik, yang masing-masing memiliki peranan tersendiri dan saling berinteraksi dalam imunopatogenesis PPOK.

Inflamasi saluran napas pada PPOK akan menetap meskipun telah berhenti merokok, hal ini dapat disebabkan oleh karena kerusakan matriks ekstraseluler akan melepaskan sitokin proinflamasi yang merupakan kemotaksis netrofil dan monosit, gangguan fungsi makrofag alveolar yang mengakibatkan gangguan pembersihan sel apoptosis dan mikroba patogen, dan stres oksidatif yang akan menyebabkan kerusakan rantai ganda DNA.

\section{DAFTAR PUSTAKA}

1. Perhimpunan Dokter Paru Indonesia (PDPI). PPOK. Diagnosis dan Penatalaksanaan. Jakarta: UI-Press, 2016. 3-18

2. Global Initiative for Chronic Obstructive Lung Disease (GOLD). Global strategy for the diagnosis, management and prevention of chronic obstructive pulmonary disease update 2015

3. Joshua JS, Thomas PS. COPD: Immunopathogenesis and Immunological and BioMarkers. Advanced in Research. 2015, 3(2): 221-235

4. Shaykhiev R, Crystal RG. Early events in the pathogenesis of chronic obstructive pulmonary disease. Smoking-induced reprogramming of airway epithelial basal progenitor cells. Ann Am Thorac Soc. 2014;11(5):252-8.

5. de Boer WI, Hau CM, van Schadewijk A, et al. Expression of epidermal growth factors and their receptors in the bronchial epithelium of subjects with chronic obstructive pulmonary disease. Am J Clin Pathol. 2006; 125: 184-92.

6. Vlahos R, Bozinovski S. Role of Macrophage in COPD. Frontiers in immunology. 2014:5:435

7. Barnes PJ. Alveolar Macrophages as Orchestrators of COPD. COPD. 2004:1(1):59-70

8. Barnes PJ. Cellular and Molecular Mechanisms of Chronic Obstructive Pulmonary. Clin Chest Med. 2014: 35: 71-86

9. Hoenderdos K Condliffe A. The Neutrophil in Chronic Obstructive Pulmonary Disease.Too Little, Too Late or Too Much, Too Soon?. Am J Respir Cell Mol Biol. 2013: 48: 5:531-539

10. Kim S, Nadel JA. Role of Neutrophils in Mucus Hypersecretion in COPD and Implications for Therapy. Treat Respir Med. 2004; 3 (3): 147-159

11. Banchereau J, Briere F, Caux C, Davoust J, Lebecque S, Liu YJ, Pulendran B, and Palucka K. Immunobiology of dendritic cells. Annu Rev Immunol. 2000:18:767-811

12. Condon TV, Sawyer RT, Fenton MJ, Riches DW. Lung dendritic cells at the innate-adaptive immune interface. J Leukoc Biol. 2011; 90: $883-95$ 
13. Van Pottelberge GR, Bracke KR, Joos GF, Brusselle GG. The role of dendritic cells in the pathogenesis of COPD: liaison officers in the front line. COPD. 2009; 6: 284-90.

14. Brusselle GG, Joos GF, Bracke KR. New insights into the immunology of chronic obstructive pulmonary disease. Lancet. 2011; 378: 101526.

15. Pouwwels SD, Heeijink IH, ten Hacken NHT, Vandenabeele P, Krysko DV, Nawijn MC, van Oosterhout AJM. DAMPs activating innate and adaptive immune responses in COPD. Mucosal Immunology. 2014: $7(2)$.

16. Cosio MG, Saetta M, Agusti A. Immunologic Aspects of Chronic Obstructive Pulmonary Disease. N Engl J Med 2009; 360: $2445-$ 54.

17. Cosio MG, Majo J. Inflamation of the Airways and Lung Parenchyma in COPD, Role of T Cells. CHEST. 2002; 121:160S-165S.
18. Randall TD. Bronchus-associated lymphoid tissue (BALT) structure and function. Adv Immunol 2010; 107: 187-241

19. Mueller SN, Hosiawa-Meagher KA, Konieczny BT, et al. Regulation of homeostatic chemokine expression and cell traffi cking during immune responses. Science 2007; 317: 670-74.

20. Kirkham PA, Barnes PJ. Oxidative Stress in COPD. CHEST. 2013; 144 (1): 266 - 273

21. Abboud RT, Vimalanathan S. Pathogenesis of COPD. Part I. The role of protease-antiprotease imbalance in emphysema. Int J Tuber Lung Dis. 2008;12(4):361-367.

22. Aoshiba K, Tsuji T, Yamaguchi K, Itoh M, Nakamura H. The danger signal plus DNA damage twohit hypothesis for chronic inflammation in COPD. Eur Respir J. 2013; 42: 1689-1695. 